THE GRAND STRATEGIST'S CREDO

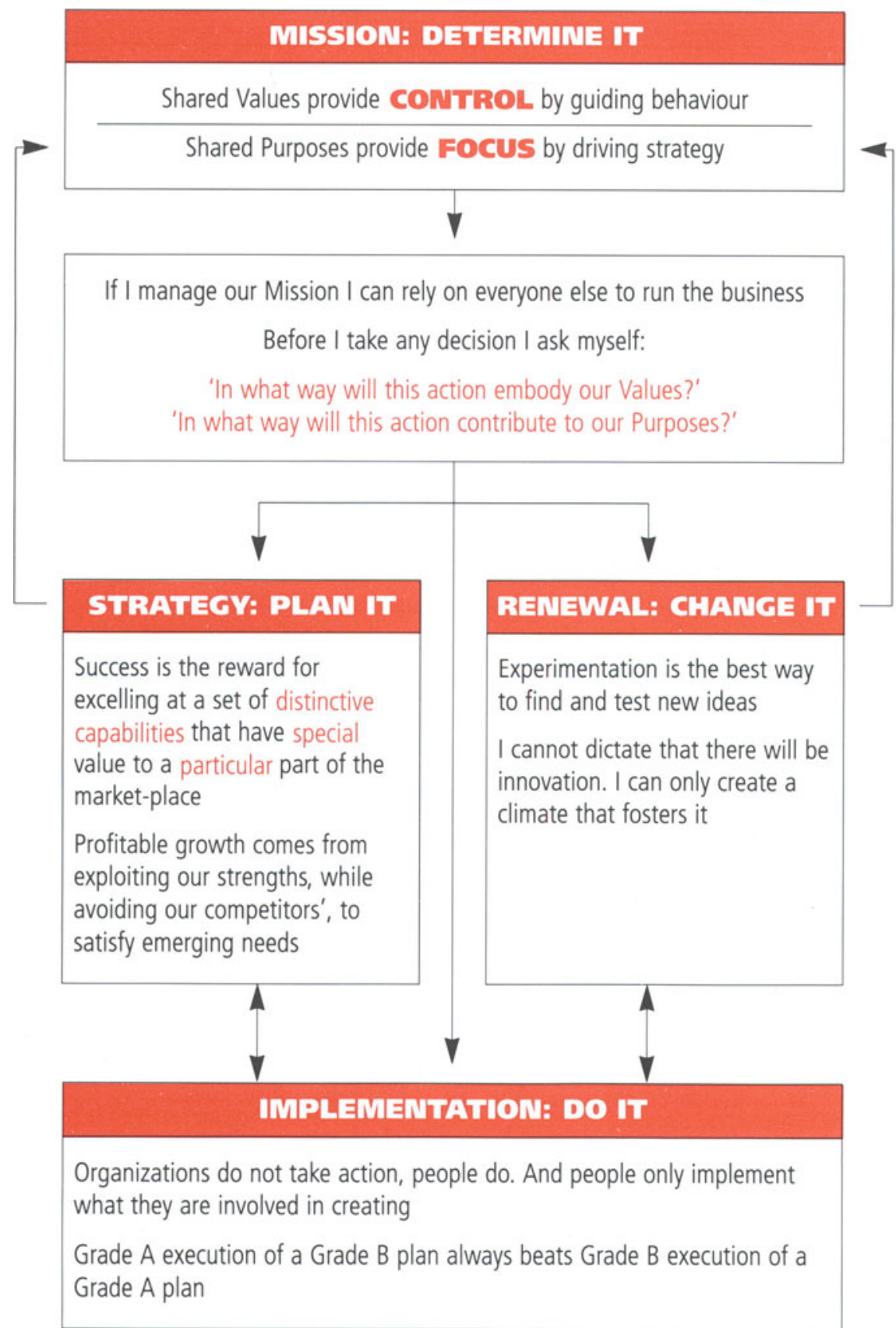




\section{STRONGER STRATEGIC POSITIONS}

My people know more about their business than I do. I help them not to fail by making sure they take account of the principles of competition:

\section{DIRECTION}

1 How clear and achievable are their goals?

2 Are they exploiting emerging trends quickly and effectively?

\section{FOCUS}

3 Do they have superior scale in the critical resource areas?

4 Are they using resources efficiently and with minimum waste?

5 Have they built enough flexibility of resources into their plans?

\section{IMPLEMENTATION}

6 Does the plan have the ability to gain key people's commitment?

7 How well are they creating barriers to competitive countermoves?

8 How unexpected and original is what they plan to do?

9 How simple are their plans to understand and implement?

\section{HIGHER QUALITY IMPLEMENTATION}

Selection, evaluation and training are my most powerful tools for fulfilling our mission. I will:

- inculcate and reward personal responsibility and individual initiative in every one of my people

a pay close attention to detail when it matters to my strategy, and not pick my people's plans to pieces when it doesn't

- learn from our mistakes and be objective in my evaluation of our experience

a allow no exceptions to our mission, and go to any lengths to be true to it

\section{MORE EFFECTIVE RENEWAL}

How I spend my time, what I reward . . . and punish, whom I promote and where I allocate our resources will determine the real climate of my organization. I will:

a conduct all our affairs in a spirit of play, and make sure it is possible for everyone else to do the same

model and reinforce the ability to work in groups

- encourage constructive argument and help my people enjoy it

remain open to criticism, and never shoot the bearers of bad news 
THE GRAND STRATEGIST 


\title{
MIKE DAVIDSON
}

\section{'Concentrated wisdom — easy reading'}

\section{'The best speaker on strategy}

I've ever heard'

\section{CONTROL YOUR OWN DESTINY}

\author{
WIN MORE - FAIL LESS
}

ACHIEVE MORE WITH THE HOURS YOU SPEND

\section{AND ABOVE ALL - ENJOY DOING IT}



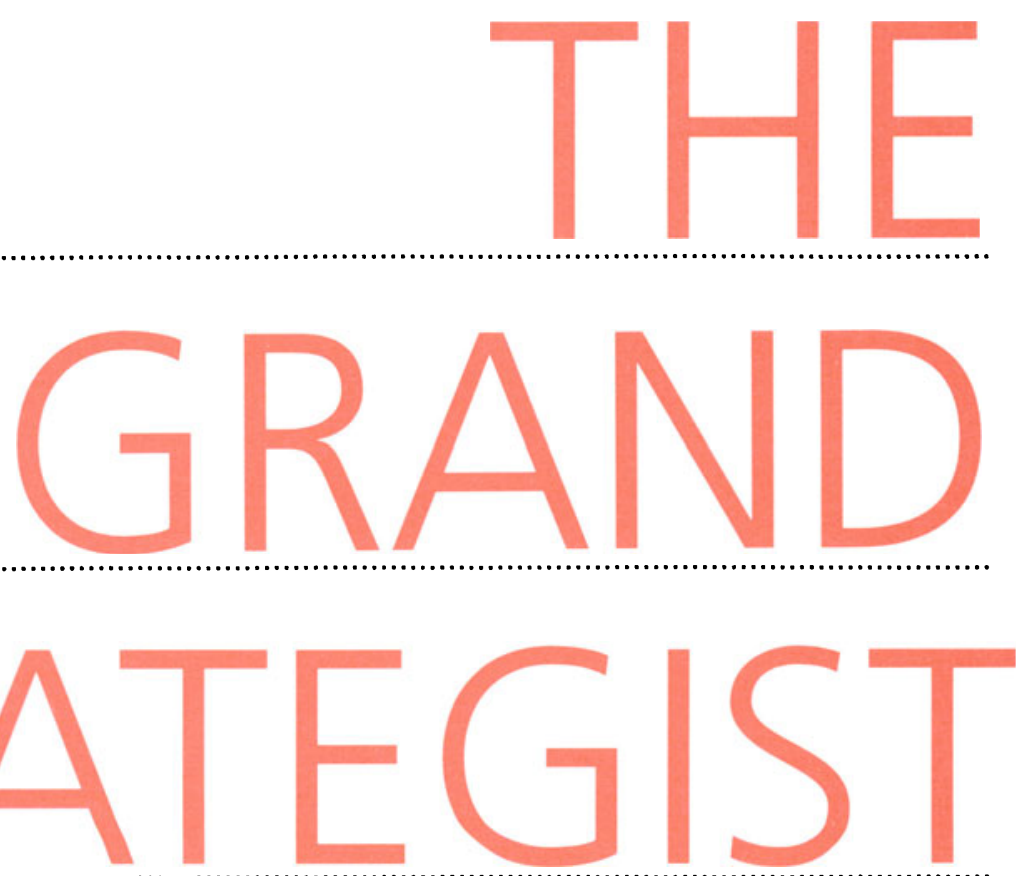

\section{THE \\ REVOLUTIONARY \\ NEW MANAGEMENT \\ SYSTEM}

PALGRAVE MACMILLAN 
FOREWORD:

\section{MISSION:}

\section{COMPETITION:}

PERFORMANCE:

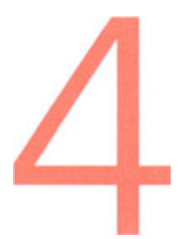

\section{ChANGe:}

CONCLUSION: 
What are we trying to do? 5

\begin{tabular}{llr}
1 & Help! & 7 \\
\hdashline 2 & The Grand Strategist & 13 \\
\hdashline & The Magic of Mission & 29
\end{tabular}

How do we gain a competitive edge? 35

1 The Aim of Strategy 37

2 The Secret of Success $\quad 45$

3 Adding Strategy to Operations $\quad 49$

How do we deliver results? 61

1 The Doers Must be the Planners $\quad 64$

2 Implementation Beats Planning 65

3 Institutionalizing Excellence 66

How do we cope with change? 75

1 Nothing Fails Like Success $\quad 77$

2 Don't Research - Experiment 83

3 Fostering Innovation $\quad 87$

The Winning Organization 95

1 Leadership 97

2 The New Grand Strategist 103

3 You Can Be One Too 105 


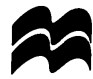

First published 1995 by Macmillan London Limited

an imprint of Macmillan General Books Limited

Cavaye Place London SW10 9PG

and Basingstoke

ISBN 978-1-349-13721-3 ISBN 978-1-349-13719-0 (eBook)

DOI 10.1007/978-1-349-13719-0

Copyright (C) Mike Davidson 1995

Softcover reprint of the hardcover 1st edition 1995 978-0-333-63651-0

The right of Mike Davidson to be identified as

author of this work has been asserted by him in

accordance with the Copyright, Design and Patents Act 1988.

All rights reserved. No reproduction, copy or transmission of this publication may be made without written permission. No paragraph of this publication may be reproduced, copied or transmitted save with written permission or in accordance with the provisions of the Copyright Act 1956 (as amended). Any person who does any unauthorized act in relation to this publication may be liable to criminal prosecution and civil claims for damages.

98765432

A CIP catalogue for this book is available from the British Library 


\section{FOREWORD: \\ THE AGE OF STRATEGIC MANAGEMENT}

Every organization has competitors. Businesses compete to sell their products and services. Cities and states compete to attract new industries, contracts or government funds. Schools and universities compete for students and to attract and hold a talented faculty. Start-up ventures and small companies compete for scarce resources to ensure their very survival. For a whole generation after the Second World War, a healthy, growing economy left room for many competitors to prosper alongside each other. Then in one decade, the seventies, the advent of a global market, scarce resources, expensive money and the end to steady growth changed the rules of the game. Achieving the absolute goals of an organization now depends on relative success. The search for a competitive edge, and management of the entire corporation to achieve and sustain it, are the central operating tasks of our time.

Strategic management creates the competitive edge that makes winners. It harnesses all the potential of an organization to this end by causing every day-to-day operating decision to be made in a pre-eminently strategic manner. Everything is done 
with the intention of securing competitive advantage. Strategic management is therefore a task for the whole organization all the time, not the province of specialists or a once-yearly undertaking. It is a way of thinking, a guide to action and the determinant for the behaviour of every member of the organization. Its goal is the creation of a set of distinctive capabilities, that have special value to a particular part of the market-place. By doing so it positions the organization for the sustained, superior performance that is the mark of strategic success.

While recognition of the need to manage in this way is growing, it has seldom been put successfully into practice. The principal reason for this lack of success has been our belief that strategy should concentrate on improving the allocation of our financial resources.

We have become very good at it. But so has everyone else, leaving little opportunity for achieving a winning margin. But still some companies outperform others. They are the few who have remembered a more important set of resources - the human ones. Behaviour turns out not just to matter but to be the determining factor. It provides the margins of competitiveness which dictate who wins and who merely participates.

Above all else, strategic management brings about individual and group behaviour that results in competitive advantage. It is first and foremost the management of people, not money. Why have most of us missed it?

We have been pursuing the wrong goal - the making of 
money, not the creation of wealth. The business schools, so long the scapegoat, are a symptom not the cause. Society has put the rapid accumulation of personal riches at the pinnacle of success. The business schools, as good market-oriented institutions, have filled the need. The result has been too many manipulators of money and too few managers of people.

Lack of competitiveness cannot be blamed on the failure of educational institutions, loss of work ethic or a superior Japanese system. It is the result of narrow vision and the failure to lead.

To quote Thomas Watson, Jr, ‘. . the real difference between success and failure in a corporation can very often be traced to the question of how well the organization brings out the great energies and talents of its people.'

That insight was the mark of a tiny number of outstanding companies when it was written in the mid-sixties. In an era marked by unprecedented competitive intensity and accelerating change, it has become a condition for survival. Today a whole new breed of leaders is managing by identifying the shared values that can create common cause, and developing the shared vision that can inspire the winning effort. In so doing they are at last ushering in The Age of Strategic Management. This book is dedicated to that new breed of leader - The Grand Strategist. 